\title{
麻疹・風疹混合 $(\mathrm{MR})$ ワクチンの 2 回接種における
}

\section{安全性と有効性}

\author{
${ }^{1)}$ 川崎医科大学小児科, ${ }^{27}$ 国立病院機構三重病院, ${ }^{37}$ 国立病院機構福岡病院, ${ }^{4}$ 国立感染症研究所 \\ 寺田 喜平 ${ }^{12}$ 尾内 一信 ${ }^{1)}$ 庵原 俊昭 ${ }^{2}$ \\ 岡田 賢司 ${ }^{3)} \quad$ 沼崎＼cjkstart啓 ${ }^{4)}$
}

(平成 19 年 11 月 28 日受付)

(平成 20 年 5 月 19 日受理)

\author{
Key words: measles, rubella, MR vaccine, efficacy, safety
}

\section{要旨}

麻疹・風疹混合（MR）ワクチン 2 回接種に扔ける安全性と有効性について検証を行った．対象は約 5 年 前 1 歳で接種したMR ワクチン（ミールビック, 財団法人阪大微生物病研究会）治験対象者うち了解の得 られた 75 名であった．方法は追加接種前後に採血して抗体価の変動を調べ，接種後 28 日間の健康状態観察 表から有害事象を調査した，その結果，重症な有害事象は認められなかった．また発熱の頻度は 1 回目の接 種時より有意に（p<0.05）27.3\% から 14.9\%, 発疹の頻度も $12.2 \%$ から $6.8 \%$ に減少したが有意差はなかっ た．接種部位の発赤や腫脹は, それぞれ $7.3 \%$ から $10.8 \%, 2.9 \%$ から $8.1 \%$ に増加したが, 有意差はなかっ た. 有効性において, 追加接種前後で麻疹 NT 抗体 $\left(2^{\mathrm{n}}\right)$ の平均士標準偏差は $5.5 \pm 1.2$ から $6.4 \pm 1.0$ に増加し, $\mathrm{p}<0.0001$ の有意差があった. 風疹 HI 抗体 $\left(2^{\mathrm{n}}\right)$ の平均 標準偏差は $4.5 \pm 1.3$ から $6.3 \pm 0.9$ に増加し, 統計 学的には $\mathrm{p}<0.0001$ の有意差があった. 2 回目接種後麻疹抗体は NT 法および EIA 法で, 風疹抗体は HI 法 ですべて陽性となった，接種後平均で 2 管以上の有意な増加を認めた接種前抗体価は, 麻疹 $\mathrm{NT}$ 抗体 8 倍以 下, 風疹 $\mathrm{HI}$ 抗体 16 倍以下であった，以上ょり, MR ワクチン 2 回接種は安全で有効な方法と考えられた.

〔感染症誌 $82: 414 \sim 418$, 2008]

\section{序 文}

わが国では 1989〜1993 年まで麻疹・ムンプス・風 疹混合 (MMR) ワクチンが使用されていたが，その 中のムンプスワクチンによる無菌性髄膜炎の増加のた め使用中止となった。しかし，世界のほとんどの国で は MMR ワクチンによる 2 回接種が実施されている. またWHO がすべての小児に対し麻疹ワクチンの 2 回 接種を求め, さらに西太平洋地域における麻疹排除は 2012 年までに達成する目標を掲げた。 わが国でも麻 疹・風疹混合 $(\mathrm{MR})$ ワクチンが使用可能となり, 2006 年 4 月 1 日より MR ワクチンが導入され, 同年 6 月 より MRワクチンの 2 回接種が実施されている. し かし，わが国では 2 回接種が広く行われた経験がない ため, 2 回接種の安全性と有効性について検討を実施 することになった. 2 回接種には 2 種類存在し, 麻疹 と風疹の単抗原ワクチン接種後に MR ワクチンを接

別刷請求先 : ( ₹701-0192) 倉敷市松島 577 川崎医科大学小坚科

寺田 喜平
種する場合と MR ワクチン接種後の MR ワクチン接 種の場合がある.今回, 我々は後者について検討した ので, その結果を報告する.

\section{対象と方法}

対象は, MR ワクチン（ミールビック；財団法人阪 大微生物病研究会）治験に同意し，1歳で接種した小 児である. その治験対象者に MR ワクチン接種の約 5 年後, 小学校就学前に 2 回目の同ワクチン接種（ミー ルビック）を颃願いした. 保護者からインフォームド コンセントを得られた小児について登録を行った.こ の調査の実施については, 川崎医科大学倫理委員会の 承認を得た。

安全性（有害事象調査）に関して, 保護者に接種後 28 日間健康状態観察表を記載してもらい, すべての 有害事象を調査した。発熱の定義は $37.5^{\circ} \mathrm{C}$ 以上, 接 種部位の発赤や腫脹は直径 $1 \mathrm{~cm}$ 以上とした.

MR ワクチンの有効性に関しては, (1)接種前採血し, 2 回目の MR ワクチンを $0.5 \mathrm{cc}$ 皮下接種する. (2)接種 
後 6〜8 週間に採血を行う。麻疹抗体は中和 $(\mathrm{NT})$ 法 $^{1)}$, 赤血球凝集抑制 $(\mathrm{HI})$ 法 $^{2}$ ，酵素免疫 (EIA) 法（デンカ 生研キット, SRL で測定)で, 風疹抗体は HI 法"2), EIA 法 (デンカ生研キット, SRL で測定) で測定した. NT 抗体はマイクロプレートで, 1 検体につき 2 列を使用 し， 1 希釈 2 穴ずつ実施した。例えば, $2^{5}$ 希釈の 2 穴 のうち 1 穴が陽性の場合は $2^{5} に な り ， 2$ 穴が陽性の場 合は $2^{5.5}$ とした. NT 法は 4 倍未満を $\mathrm{HI}$ 法は 8 倍未満 を陰性, EIA 法では 2.0 末満を陰性, 2.0〜3.9を( 4.0 以上を陽性とした。

接種前後でそれら抗体価の比較を行った. 被験者 75 名から採血できた. 統計学的処理は, 副反応の頻度の 比較は $\chi^{2}$ 検定, 接種前後における抗体価の変動は Wilcoxon 検定を使用した. $\mathrm{p}<0.05$ を有意差ありと判定 した.

\section{成 績}

登録した児は 75 名（男/女；41/34名）であった。 うち 1 名（1.3\%）からは観察表を回収できなかった。 1 回目の接種後に麻疹 NT 抗体陰性であった小児は 0 名, 風疹 $\mathrm{HI}$ 抗体院性であった小児は $6 / 75$ 名（8\%） あった。そのうち，4/6名が 2 回目接種前に抗体陽性 となっていたが, 再接種や感染の有無は不明であった.

1. 安全性調査

入院を必要とするなどの重症な有害事象はなかっ た. Table 1に, 有害事象調査の結果を示し, MR ワ クチン 1 回目接種時副反応との比較を示した。今回, MR ワクチン 1 回目接種時より追加接種において有害 事象の頻度が減少したものは, 発熱と発疹であった. 発熱は $27.3 \%$ から $14.9 \%$ に有意 $(\mathrm{p}<0.05)$ に減少し た. 発熱の程度は, 6/11名が $37.5 \sim 38.0^{\circ} \mathrm{C}, 4$ 名が $38.1 \sim 39.0^{\circ} \mathrm{C}, 1$ 名が $39.1^{\circ} \mathrm{C}$ 以上であった. またウイ ルス増殖期の接種後 4〜 15 日に限定すると 11 名から 5 名 $(6.8 \%)$ に減少した. 発疹は $12.2 \%$ から $6.8 \%$ に 減少したが有意差はなかった。 また同様にウイルス増 殖期に限定すると 5 名から 2 名 $(2.7 \%)$ に減少した. 一方, 増加したものは接種部位の発赤と腫脹であった. これらはすべて直径が $1 \sim 5 \mathrm{~cm}$ 以内で, $0 \sim 3$ 日以内 に発現していた．発赤の頻度は $7.3 \%$ から $10.8 \%$ に, 腫脹は $2.9 \%$ から $8.1 \%$ に増加したがどちらも有意差 はなかった，そのほか,リンパ節腫脹 5 名 $(6.8 \%)$, 関節痛 3 名 $(4.1 \%)$ を認めた．対象を追加接種した 75 名に限定して有害事象を比較すると, 1 回目接種後 4 15 日の発熱は $19 / 75$ 名（37.5〜 38.0 $0^{\circ}$ が 5 名, 38.1〜 $39.0^{\circ} \mathrm{C}$ が 9 名, $39.1^{\circ} \mathrm{C}$ 以上が 5 名), 発疹は 5 名, 注 射部位の発赤は 4 名, 腫脹は 1 名であった. 有意差は いずれもなかったが, 発熱の頻度は減少し, 注射部位 の発赤と腫脹は増加する傾向にあった.

2. 有効性調査
Table 1 Adverse MR vaccination reaction

\begin{tabular}{lccc}
\hline vaccination & $\begin{array}{c}\text { first } \\
\mathrm{n}=205 \\
(\%)\end{array}$ & $\begin{array}{c}\text { second } \\
\mathrm{n}=74 \\
(\%)\end{array}$ & significance \\
\hline fever & $\begin{array}{c}56 \\
(27.3 \%)\end{array}$ & $\begin{array}{c}11 \\
(14.9 \%)\end{array}$ & $\mathrm{p}<0.05$ \\
eruption & $\begin{array}{c}25 \\
(12.2 \%)\end{array}$ & $\begin{array}{c}5 \\
(6.8 \%)\end{array}$ & $\mathrm{ns}$ \\
& 15 & \\
redness at site & $(7.3 \%)$ & $(10.8 \%)$ & $\mathrm{ns}$ \\
Swelling at site & 6 & 6 & $\mathrm{n}$ \\
& $(2.9 \%)$ & $(8.1 \%)$ & $\mathrm{ns}$ \\
\hline
\end{tabular}

ns : not significant

Fever between 37.5 and $38.0^{\circ} \mathrm{C}$ occurred in six children, that between 38.1 and $39.0^{\circ} \mathrm{C}$ in four, and that of $39.1^{\circ} \mathrm{C}$ in one inoculation site redness or swelling was between 1 and $5 \mathrm{~cm}$.

Fig. 1に追加接種前後の麻疹 NT 抗体の変動を, Fig. 2 に風疹 HI 抗体の変動を示した。二次性ワクチン効 果不全 (secondary vaccine failure) の割合, すなわ ち MR ワクチン 1 回目接種後抗体陽性小児における 追加接種前の陰性化率である. 感度がよく代表的な抗 体測定法の麻疹 NT 抗体で, 1 回目陽性が確認できた 75 名中 3 名 $(4.0 \%)$ が㓌性となっていた，一方，風 疹 HI 抗体では 1 回目の接種後陽性となった 69 名の うち 11 名（15.9\%）が陰性化していた． 2 回目の接種 後麻疹抗体は, HI 抗体では 2 名 $(2.7 \%)$ が陰性のま まであったが, NT 抗体および EIA-IgG 抗体はすべて 陽性化した。接種後風疹抗体は，EIA-IgG 抗体で 1 名 (1.3\%) が（土）のままであったが, HI 抗体ではす べて陽性化した. 接種前後の抗体の変動について, Table 2に麻疹 NT 抗体価, Table 3に風疹 HI 抗体価の 平均值における変動を示した。麻疹 NT 抗体 $\left(2^{\mathrm{n}}\right)$ の 平均士標準偏差は接種前 $5.5 \pm 1.2$ から接種後 $6.4 \pm 1.0$ に増加し, 統計学的には $\mathrm{p}<0.0001$ の有意差があった. 2 回目接種後抗体価の最低值 $16\left(2^{4}\right)$ 倍は 4 名 $(5.2 \%)$ であった。一方, 風疹 $\mathrm{HI}$ 抗体 $\left(2^{\mathrm{n}}\right)$ の平均 \pm 標準偏 差は接種前 $4.5 \pm 1.3$ から接種後 $6.3 \pm 0.9$ に増加し, 統 計学的には $\mathrm{p}<0.0001$ の有意差があった. 接種後の抗 体価の最低值 $16\left(2^{4}\right)$ 倍は 1 名だけであった。麻疹 NT 抗体および風疹 $\mathrm{HI}$ 抗体も接種前抗体価が低いほど接 種後の抗体価の増加が大きい傾向であった．抗体価の 平均值で 4 倍 (2 管) 以上の有意な抗体価増加を認め たのは接種前麻疹 NT 抗体が 8 倍以下であり, 風疹 $\mathrm{HI}$ 抗体では 16 倍以下であった. それを個別に見ると, 麻 疹 NT 抗体 8 倍以下では 6/8 名 $(75.0 \%)$ が, 風疹 HI 抗体 16 倍以下では 42/46 名（91.3\%）が有意に増加 していた。麻疹 NT 抗体 16 倍では $3 / 14$ 名 (21.4\%), 32 倍では $3 / 22$ 名 $(13.6 \%)$, 風疹 $\mathrm{HI}$ 抗体 32 倍では 11 $/ 17$ 名 $(64.7 \%)$ が有意な増加を示したが, それ以上 では 1 名も有意な増加はなかった。

平成 20 年 9 月 20 日 
Fig. 1 Change in measles antibody titer distribution using NT assay after second MR vaccine vaccination

\section{Numbers}

$$
\mathrm{n}=75
$$

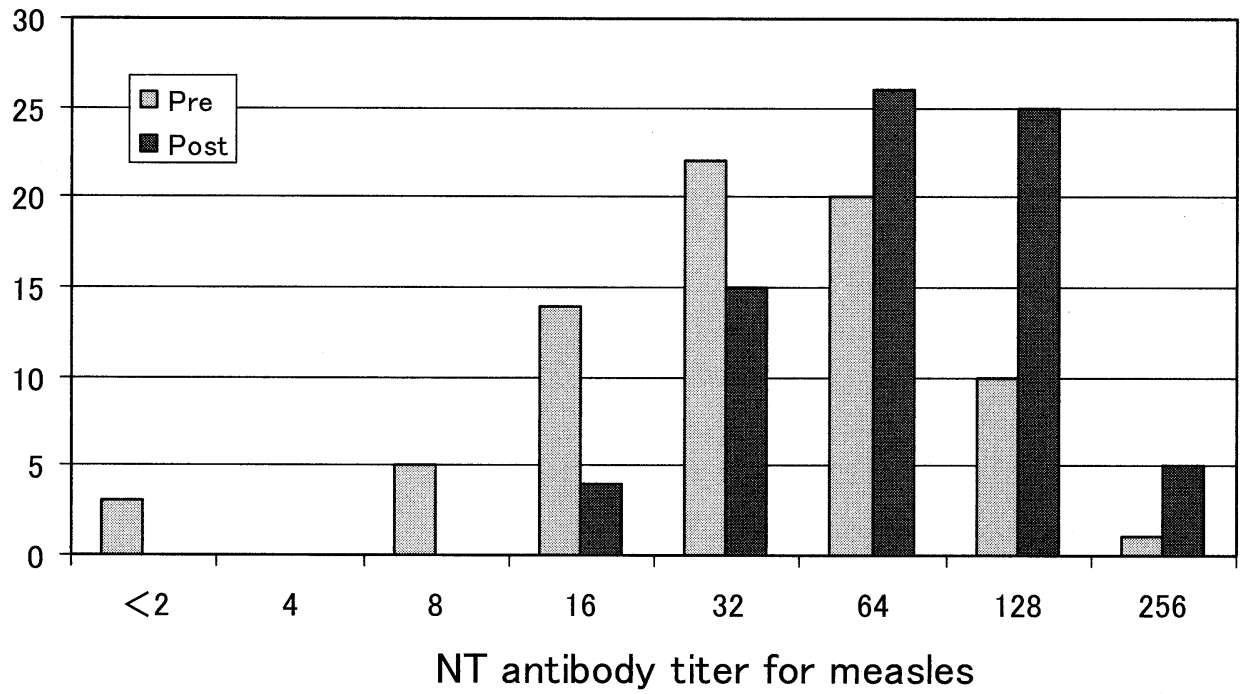

Fig. 2 Change in rubella antibody titer distribution using $\mathrm{HI}$ assay after second MR vaccine vaccination

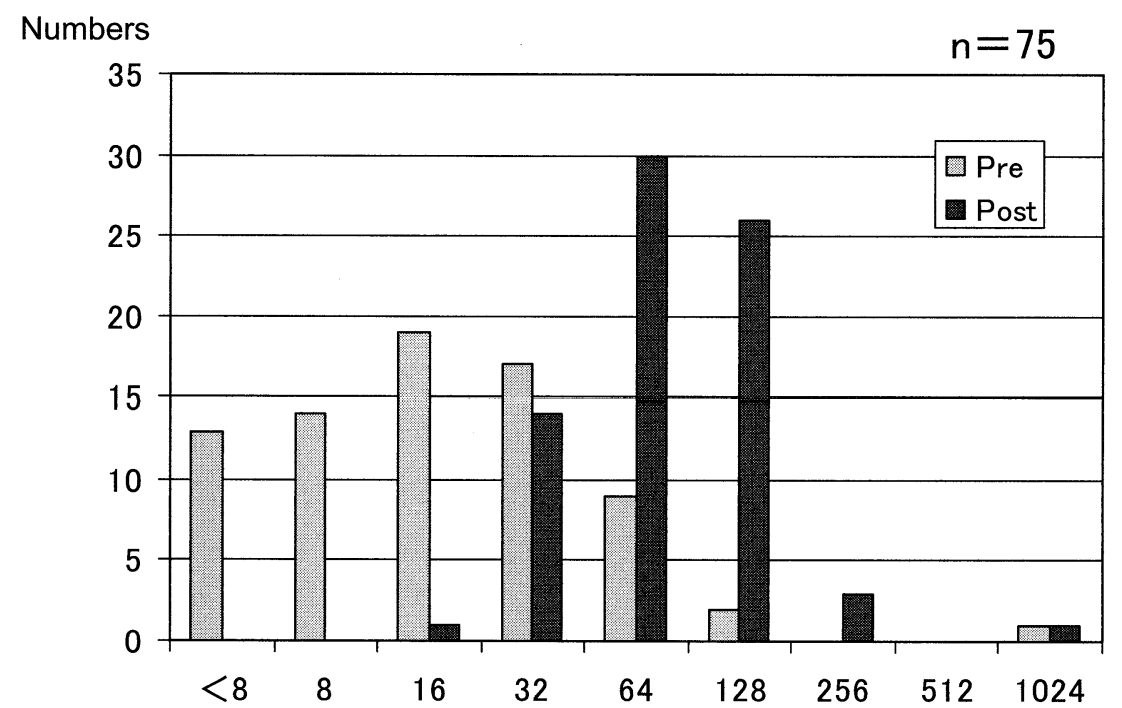

$\mathrm{HI}$ antibody titer for rubella

Table 2 Changes in measles antibody titers using NT assay after second MR vaccine vaccination

\begin{tabular}{lcccc}
\hline $\begin{array}{c}\text { Preantibody } \\
\text { titers }\left(2^{\mathrm{n}}\right)\end{array}$ & Numbers & $\begin{array}{c}\text { mean Pre- } \\
\text { antibody titer }\end{array}$ & $\begin{array}{c}\text { mean Post- } \\
\text { antibody titer }\end{array}$ & $\begin{array}{c}\text { mean Post-Pre } \\
\text { titer }\end{array}$ \\
\hline$<3.0$ & 3 & $<0.83$ & 5.17 & $>4.34$ \\
$>3.0 \&<4.0$ & 5 & 3.2 & 5.6 & 2.4 \\
$>4.0 \&<5.0$ & 14 & 4.39 & 5.71 & 1.32 \\
$>5.0 \&<6.0$ & 22 & 5.27 & 6.30 & 1.03 \\
$>6.0 \&<7.0$ & 20 & 6.28 & 6.88 & 0.6 \\
$>7.0 \&<8.0$ & 10 & 7.1 & 7.55 & 0.45 \\
$>8.0$ & 1 & 8.0 & 7.0 & -1.0 \\
\hline & 75 & $5.5 \pm 1.2$ & $6.4 \pm 1.0$ & 1.9 \\
\hline
\end{tabular}

Pre, prevaccination ; Post, postvaccination.

NT titers increased significantly $(\mathrm{p}<0.0001)$ from prevaccination to postvaccination. 
Table 3 Changes in rubella antibody titers using $\mathrm{HI}$ assay after second MR vaccine vaccination

\begin{tabular}{cccc}
\hline $\begin{array}{c}\text { Preantibody } \\
\text { titer }\left(2^{\mathrm{n}}\right)\end{array}$ & Numbers & $\begin{array}{c}\text { mean Postantibody } \\
\text { titer }\end{array}$ & $\begin{array}{c}\text { mean Post-Pre } \\
\text { titer }\end{array}$ \\
\hline$<3.0$ & 13 & 5.77 & $>2.77$ \\
3.0 & 14 & 5.79 & 2.79 \\
4.0 & 19 & 6.05 & 2.05 \\
5.0 & 17 & 6.76 & 1.76 \\
6.0 & 9 & 6.56 & 0.56 \\
7.0 & 2 & 7.5 & 0.5 \\
10.0 & 1 & 10.0 & 0.0 \\
\hline $4.5 \pm 1.3$ & 75 & $6.3 \pm 0.9$ & 1.8 \\
\hline
\end{tabular}

Pre, prevaccination; Post, postvaccination.

HI titers increased significantly $(\mathrm{p}<0.0001)$ from prevaccination to postvaccination.

\section{考察}

MR ワクチン（阪大微研；ミールビック）の治験を 受けた児 75 名に対して, 2 回目の MR ワクチンを接 種し，その安全性と有効性について検証した。 この対 象者を含んだ MR ワクチン 1 回接種における治験 205 名において, 麻疹 NT 抗体で $100 \%$, 風疹 $\mathrm{HI}$ 抗体で $98.0 \%$ の抗体陽性化が報告された ${ }^{3)}$. 発熱や発疹の頻 度はそれぞれ $14.9 \%, 6.8 \%$ と減少し, 発熱の頻度は 有意に減少した。接種対象者の多くは既に免疫を持っ ているため, ワクチンに含有されるウイルスは存在す る抗体によって中和されるため, 発熱や発疹などの副 反応は少なくなったのだろうと思われた，一方，頻度 が増加した接種部位の反応は, 一般に接種回数が増加 するにつれてその頻度は増加するが, 有意差はなかっ た. 同じ対象者で比較すると, 有意差はなかったが同 様な傾向が観察された.

単抗原の麻疹と風疹ワクチン接種約 5 年後に $\mathrm{MR}$ ワクチン（阪大微研）を接種した庵原らの報告（163 名) ${ }^{4)}$ では, 発熱 $17.9 \%$, 発疹 $5.6 \%$, 関節痛 $3.1 \%$, 注 射部位の発赤 $13.0 \%$, 腫脹 $8.0 \%$ であった。 また高山 らの報告5) (39 名）でも発熱 $16.2 \%$, 発疹 $8.1 \%$, 接種 部位の発赤や腫脹 $8.3 \%$ に認められた. どちらの報告 も重篤な副反応はなく, 我々の結果とほぼ同等であっ たと考えられた.

MR ワクチンの有効性について複数の抗体測定法で 検討したが, 2 回目の MR ワクチン接種後の麻疹抗体 陽性率は, 使用した測定法のうちもっとも感度の悪い 麻疹 HI 法でも 97\%, EIA 法, NT 法はそれぞれ 99\%， $100 \%$ であった. また風疹抗体は EIA 法で $99 \%$, HI 法で $100 \%$ 陽性であった. 庵原ら ${ }^{4)}$ および高山ら ${ }^{5)}$ の報 告でも麻疹 NT 抗体および風疹 $\mathrm{HI}$ 抗体で 2 回目接種 後 $100 \%$ 陽性であり，同等と考えられた。 また平均お よび中央值ともに 64 倍 $\left(2^{6}\right)$ 以上あり, 2 回目追加接 種後の最低抗体価は麻疹 NT および風疹 $\mathrm{HI}$ 抗体とも
に 16 倍で，それぞれ 4 名と 1 名であった.

ブースター効果は抗体価が低いほど高い傾向にあ り，庵原ら ${ }^{4)}$ おび高山ら ${ }^{5)}$ の報告でも同様な結果で あった，我々の結果では，平均值で 4 倍（2管）以上 の有意な抗体価の増加を認めた接種前抗体価は, 麻疹 $\mathrm{NT}$ 抗体で 8 倍以下, 風疹 $\mathrm{HI}$ 抗体で 16 倍以下であっ た. 麻疹 NT 抗体 16 倍では $21.4 \% ， 32$ 倍では $13.6 \%$, 風疹 $\mathrm{HI}$ 抗体 32 倍では $64.7 \%$ が有意な増加を示した が, それを越える抗体価では有意な増加はなかった。 これらはブースターをかけることができる抗体価とし て参考となり，抗体を測定した場合接種対象者を決め る判断材料となるだろう.

WHO はすべての小児に麻疹ワクチンの 2 回接種を 求めている. 1 回接種のみでは, 一次性ワクチン効果 不全（primary vaccine failure）を起こすだけでなく, 抗体が陽転化しても二次性ワクチン効果不全を起こし 陰性化することがある，大学生における我々の調查で は, ワクチン効果不全は麻疹ワクチン $7.4 \%$, 風疹ワ

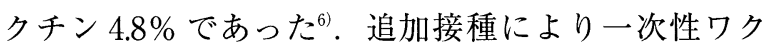
チン効果不全を防止するだけでなく，二次性ワクチン 効果不全で陰性や低下している抗体価をブースター効 果で上昇させることができるため, 将来における両疾 患の排除に有効であると考えられた，ただし，自然感 染のブースターがなくなった状況でどのくらい免疫を 維持できるか, さらに今後の検討が必要と思われた。

以上より，2011 年から実施される MR ワクチンの 2 回接種は安全にかつ有効に接種でき, 単抗原麻疹お よび風疹ワクチン接種後に MR ワクチンを追加接種 するのと同等であると考えられた.

本研究は厚生労働科学研究補助金 (新興 - 再興感染 症研究事業）「海外渡航者に対する予防接種のあり方 に関する研究 (主任研究者尾内一信)」の研究補助を 受けた。

本研究に当たりご協力頂いた，なかよしこどもクリニッ ク永吉昭一先生, 白子クリニック 小児科二井立恵先生, ト ヨ夕記念病院木戸真二先生, 市立札幌病院福島直樹先生, 大阪市立総合医療センター塩見正司先生, 外川正生先生, 三豊総合病院島内泰宏先生, 住友病院井上壽茂先生, 塚本 浩子先生, 国立病院機構三重病院中野貴司先生, 市立池田 病院牧一郎先生, 北九州市立医療センター日高靖文先生, 名古屋大学医学部木村宏先生に深謝したします.

なお，この論文の要旨は, 第 39 回日本小児感染症学会 （横浜）で発表した.

\section{文 献}

1）小船富美夫, 岡田晴恵, 佐藤 威, 小浜友昭, 田 代真人, 井上 栄, 他: 麻疹ウイルス中和試験 標準法の確立（最終案）一新たに樹立した COBL 細胞を指示細胞として一. 厚生省予防接種副反 応研究班予防接種の効果的実施と副反応に関す 
る総合的研究. 研究報告書 $1999 ;$ p. 52-5.

2) 国立予防衛生研究所学友会編 : ウイルス実験学 総論 (改訂二版), 丸善, 東京, $1973 ; 233-4, p$. 352 - 353 .

3）上田重晴：ミールビック（乾燥弱毒生麻しん風 しん混合ワクチン). 化学療法の領域 2005； $21: 121-6$.

4）庵原俊昭, 岡田賢治, 中野貴司, 神谷 斎, 二 井立恵, 伊佐地真知子, 他：麻疹ワクチン・風 疹ワクチン接種小児への麻疹・風疹混合 $(\mathrm{MR})$ ワクチン追加接種の有効性・安全性の検討. 麻 疹・風疹 $(\mathrm{MR})$ 混合ワクチンの接種効果・安全
性・接種率に関する研究. 研究報告書 2007 ; p. 25 - 31 .

5）高山直秀, 柴田雄介, 高橋菜穂子, 細部千晴, 松 永貞一, 三輪操子, 他 : 1 歳で単抗原麻しんワク チンおよび風疹ワクチン接種を受けた小児への 麻疹・風疹 2 種混合 (MR) ワクチン追加接種の 効果と安全性. Prog Med 2006；26：2583-7.

6) 寺田喜平, 小坂康子, 新妻隆広, 荻田聡子, 片 岡直樹：大学入学時における既往歴および接種 歴調査と抗体検査の比較. 日小児会誌 2006 ; $110: 767-72$.

Safety and Efficacy in Two-dose Vaccination Using Measles and Rubella Combined (MR) Vaccine

\author{
Kihei TERADA ${ }^{1)}$, Kazunobu OUCHI ${ }^{1)}$, Toshiaki IHARA $^{2)}$, Kenji OKADA ${ }^{3)}$ \& Kei NUMAZAKI ${ }^{4)}$ \\ ${ }^{1)}$ Department of Pediatrics, Kawasaki Medical School, \\ ${ }^{2}$ Department of Pediatrics, Mie Hospital, \\ ${ }^{3}$ Department of Pediatrics, Fukuoka Hospital, \\ ${ }^{4)}$ Japanese National Institute of Infectious Diseases
}

Measles and rubella combined (MR) vaccine and two-dose-vaccination have been used in Japan since 2006. only children undergoing monovalent measles and rubella vaccination undergo a second vaccination. We intend to administer MR vaccine twice to Japanese children from 2011, so studied the safety and efficacy of two-dose MR vaccination. Subjects were 75 pre school children undergoing MR vaccine manufactured by Biken at one year old in a clinical trial. Children were observed for adverse events for 28 days after the second MR vaccination. Efficacy was determined by measuring antibodies for measles and rubella before and after (six to eight weeks later) the second vaccination. Results showed that fever frequency decreased significantly from $27.3 \%$ to $14.9 \%(\mathrm{p}<0.05)$, and eruption decreased from $12.2 \%$ to $6.8 \%$ from the first to the second vaccination, whereas, the frequency of redness and swelling at the inoculation site increased from $7.3 \%$ to $10.8 \%$ and $2.9 \%$ to $8.1 \%$. Differences are not statistically significant. Measles antibody titer determined by NT assay and rubella antibody titer measured by $\mathrm{HI}$ assay increased significantly from prevaccination to postvaccination $(\mathrm{p}<0.0001)$. Measles antibodies measured by NT and EIA assays and rubella antibody measured by HI assay turned positive in all subjects after the second MR vaccination. In conclusion, two-dose MR vaccination should be safe and effective in eliminating measles and rubella in Japan. 